\title{
Texas facilities count cost of tropical storm
}

Rex Dalton, San Diego

A week after a tropical storm flooded research facilities in Houston, Texas, many scientists were still locked out of their labs, assessing a disaster that has wiped out years of studies on a variety of diseases.

More than 30,000 research animals mostly mice and rats - were destroyed, an untold number of reagents obliterated and many investigations wrecked by the record rainfall from tropical storm Allison, which swept in off the Gulf of Mexico in the early morning of 9 June.

The rain flooded basements and knocked out power to research buildings and hospitals on the sprawling Texas Medical Center campus on the city's south side - a vast biomedical complex that attracts nearly $\$ 1$ billion of grant support each year from the US National Institutes of Health (NIH).

Research facilities at Baylor College of Medicine and the University of Texas Health Science Center at Houston were hit hardest by the storm. A week later, Baylor's eight research buildings were operating on a maintenance basis only, with researchers and

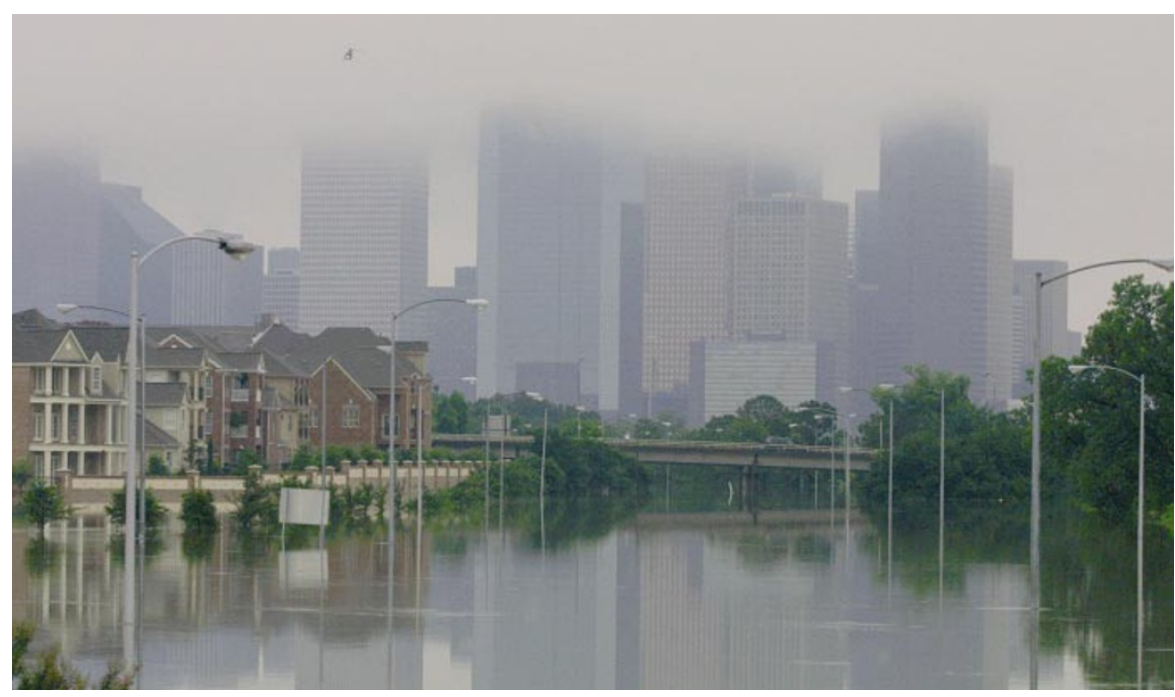

Calm after the storm: the floods in Houston washed away years of work at the city's laboratories.

students working to minimize long-term damage. The main University of Texas research building in Houston remained closed, along with the adjacent Memorial Hermann Hospital.

\section{Congress cautious on advice office}

\section{Matthew Davis, Washington}

Science-policy experts met in Washington on 14 June in a bid to revive the Office of Technology Assessment (OTA), the science and technology advisory unit that Congress disbanded in 1995.

But before the meeting, which discussed five alternative models for the office, congressmen offered up some advice of their own: don't worry too much about the details, and don't expect action on the matter any time soon.

With law-makers facing a raft of difficult science-related issues, many academics and policy experts say that Congress should restore something akin to the OTA.

But the chair of the House Science Committee, Sherwood Boehlert (Republican, New York), said that Congress already has too much scientific information. He added that it can also turn to the National Academy of Sciences for detailed advice, and expand the role of the Congressional Research Service and the General Accounting Office if more input is needed.

Boehlert nonetheless co-sponsored a bill introduced last week by Rush Holt (Democrat, New Jersey) to revive the OTA and give it an annual budget of \$20 million.

But Vernon Ehlers (Republican, Michigan) warned that many Republicans

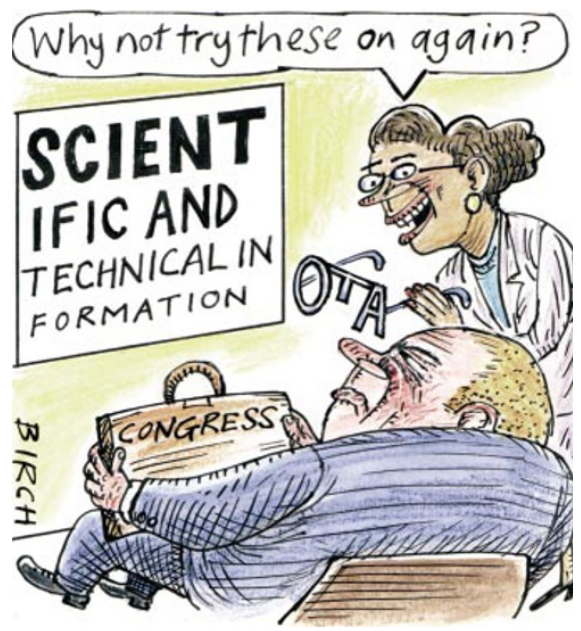

still think of the OTA as serving Democrats' partisan interests and producing reports too ponderous for practical use. He said that Congress instead needs a means of tapping technical expertise at two or three days' notice, given the speed of legislation.

Granger Morgan of the department of engineering and public policy at Carnegie Mellon University in Pittsburgh, who organized the meeting, says Congress needs an independent body to give it a sound basis for decision-making. "They need more than bare facts and brief interactions with technical experts," he says.
James Patrick, dean of research at Baylor, said that 30,000 of the institution's 130,000 research rodents have been destroyed. "A large portion of these were genetically modified mice," says Patrick.

"It is a major setback that reagents are lost," says Baylor geneticist Huda Zoghbi, "but the significant loss is time - all the work that will have to be repeated. Many of us collaborate with researchers everywhere. The impact of this will be worldwide."

On the afternoon after the flood, Katherina Walz, a postdoc working in the laboratory of geneticist James Lupski, found that more than two years of chromosomal-engineering experiments were destroyed when her colony of 150 mice drowned. "I just cried," says Walz, when she learned what happened.

Fortunately, Walz says, she discovered that three female mice - created with a genetic deficiency to mimic the Smith-Magnis mental-retardation disease - survived in another research building. It will take her more than six months to breed sufficient mice for experiments. "I feel like now I want to work more than I did before," she says.

Federal officials have declared the research region a disaster area, which means that special repair funding will be available. $\mathrm{NIH}$ officials are also waiving grant reporting requirements for researchers who have to repeat experiments. The Texan institutions are adding up the damage for insurance firms, with the total expected to run into millions of dollars.

Emergency generators were still providing power at the Baylor facilities a week after the storm, with lab directors concerned that freezers holding specimens and cultures could overheat. Before the generators were brought in, students, postdocs and professors carried tonnes of dry ice up flights of stairs to keep the specimens frozen. 